\title{
Grociana piccola: a rare example of Republican military fortifications in Italy
}

Federico Bernardini ${ }^{1}$ (D) Jana Horvat ${ }^{2}$, Giacomo Vinci ${ }^{3}$, Tina Berden ${ }^{2}$, Lucija Lavrenčič², Lucia Liccioli $^{4}$, and Carmine Lubritto ${ }^{5}$

${ }^{1}$ Department of Humanistic Studies, Università Ca'Foscari and Multidisciplinary Laboratory, The

"Abdus Salam" International Centre for Theoretical Physics <federico.bernardini@unive.it>

${ }^{2}$ ZRC SAZU, Inštitut za arheologijo <jana.horvat@zrc-sazu.si><tina.berden@zrc-sazu.si> $<$ lucija.lavrencic@zrc-sazu.si>

${ }^{3}$ Dipartimento di Matematica e Geoscienze, Università di Trieste, and Multidisciplinary Laboratory,

The "Abdus Salam" International Centre for Theoretical Physics < giacomo8vinci@gmail.com>

${ }^{4}$ INFN Sezione Firenze, Florence <lucia.liccioli@fi.infn.it>

${ }^{5}$ Dipartimento di Scienze e Tecnologie Ambientali Biologiche e Farmaceutiche, Università della

Campania "Luigi Vanvitelli" <carmine.lubritto@unicampania.it>

\begin{abstract}
Recent investigations at Grociana piccola, a site in northeastern Italy consisting of two subrectangular fortifications, offer the rare opportunity to investigate Early Roman military architecture outside the Iberian peninsula. Excavations have revealed an inner rubble masonry rampart dated to the 2nd c. BCE by associated pottery, mainly amphora remains. This date suggests that the fortification was in use during the first Roman conquest and/or later campaigns of the $2 \mathrm{nd} \mathrm{c.} \mathrm{BCE,} \mathrm{providing}$ one of the earliest and smallest examples of a military fort. The fort's ramparts were built using the same building technique as much larger 2nd-c. BCE military camps. Another trench uncovered the northeastern corner of the outer rampart and a probable tower or artillery platform which can be connected to a temporary camp built during the mid-1st c. BCE.
\end{abstract}

Keywords: Grociana piccola, northeastern Italy, fortifications, military architecture, Roman Republic

\section{Introduction}

Recent interdisciplinary investigations close to Trieste (northeastern Italy) have identified a group of Roman Republican military fortifications and their surrounding archaeological landscape. ${ }^{1}$ The fortification system, aligned facing northern Istria, consists of a large main camp (more than 13 ha) located on the San Rocco hill, flanked by two smaller structures, $4 \mathrm{~km}$ to the northeast at Grociana piccola (ca. $2 \mathrm{ha}$ ) and $1.4 \mathrm{~km}$ to the southwest at Montedoro (ca. 0.4 ha; Fig. 1). Stray finds from San Rocco and Grociana piccola have allowed a preliminary chronology to be proposed. San Rocco seems to have been first occupied in the first half of the 2nd c. BCE and one possible context for this could have been the conflict variously labeled the Second or Third Istrian War (178-177 BCE). ${ }^{2}$ Occupation appears to have continued into the 1st c. BCE, though this may not have been only for military purposes. ${ }^{3}$ Amphora fragments and metal finds from Grociana piccola have suggested that the site was occupied between the end of the 2nd c. BCE and the mid-1st c. BCE. ${ }^{4}$

$1 \quad$ Bernardini 2019; Bernardini et al. 2013, 2015, 2018; Vinci et al. 2019.

2 Bandelli 2004, 102, with relevant literature.

3 Bernardini 2019.

$4 \quad$ Bernardini et al. 2013, 2015; Bernardini 2019.

(C) The Author(s), 2021. Published by Cambridge University Press. This is an Open Access article, distributed under the terms of the Creative Commons Attribution licence (http://creativecommons.org/licenses/by/4.0/), which permits unrestricted re-use, distribution, and reproduction in any medium, provided the original work is properly cited. 


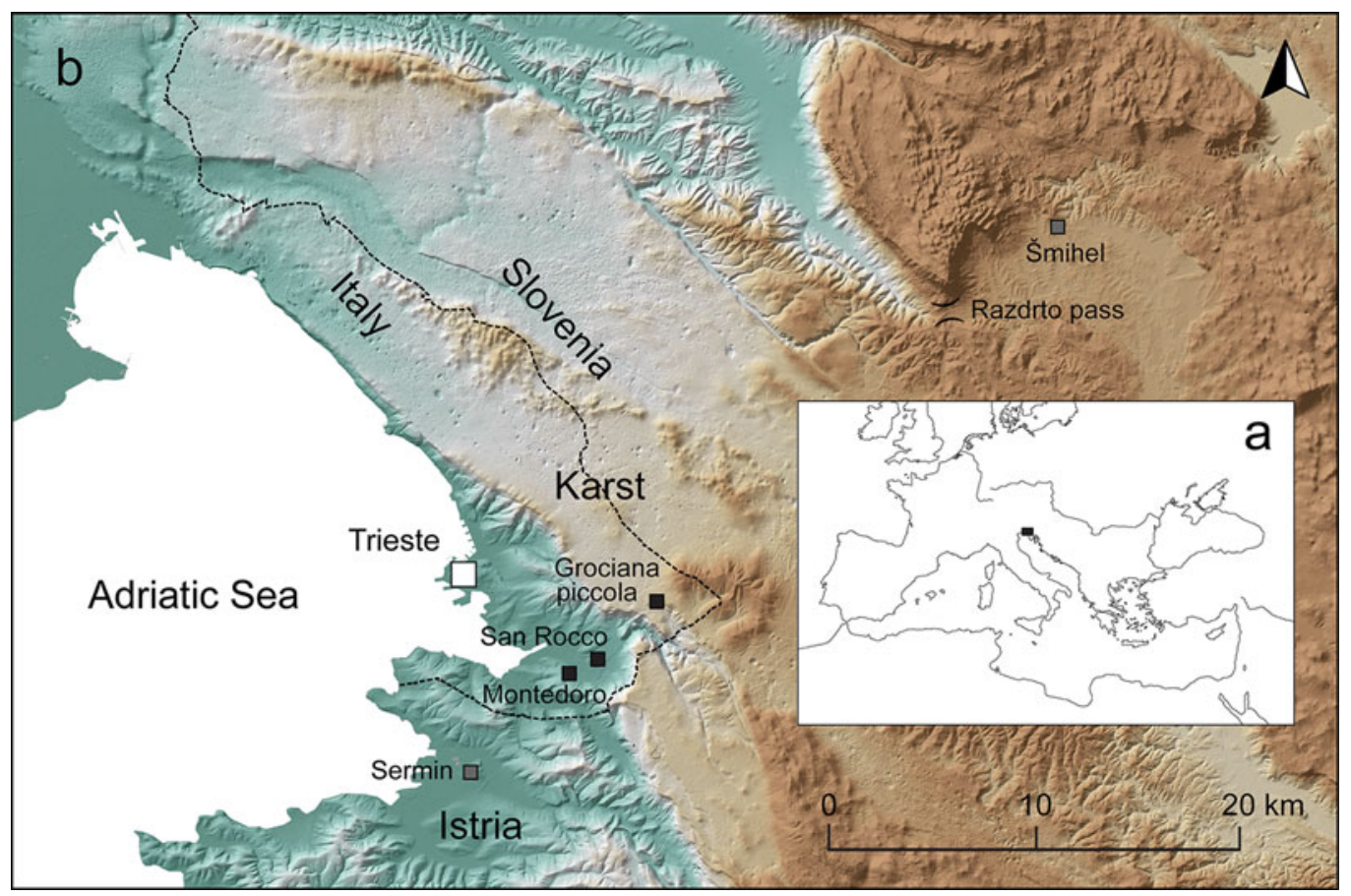

Fig. 1. (a) Position of the investigated area; (b) location of the Trieste fortifications and other sites mentioned in the text.

Field walking and small-scale excavations were carried out at Grociana piccola between 2016 and 2019, in order to explore its chronology, building technique, and historical significance. ${ }^{5}$ This paper presents the results obtained and discusses them in connection with the Roman conquest of the northeastern Adriatic and the development of Roman military architecture. The study of fortifications in the Trieste area can shed light on Roman Republican military architecture, so far mostly known from sites located in the Iberian peninsula, where there are some of the best-preserved and earliest examples of military installations, dating back to the 2nd c. BCE. Among these are the Pedrosillo fortifications, dated to the Lusitanian Wars (155-38), ${ }^{6}$ and the sites from the Numantia area, mostly related to the Numantine War (154-33 BCE). ${ }^{7}$

\section{Fortifications}

Mt. Grociana piccola is located in the Trieste Karst (Fig. 1). It overlooks part of the Karst plateau to the north and south and the Muggia Bay in the Trieste gulf to the west, as well as the routes leading from the sea north toward Aquileia, inland toward the area of modern Slovenia, and southeast to the Quarnero gulf (in modern Croatia). The site therefore had significant strategic importance. Grociana piccola, intervisible with San Rocco, could

5 Concessione di ricerche e scavi archeologici 2019 - D. Lgs. 22.01.2004, n. 42, artt. 88-89, prot. n. DG 23009-P issued on 21 August 2019.

$6 \quad$ Morillo Cerdán et al. 2011.

$7 \quad$ Dobson 2008; Morillo Cerdán 2014; Morillo Cerdán and Morales Hernández 2015; Jiménez et al. 2017, 2020. 


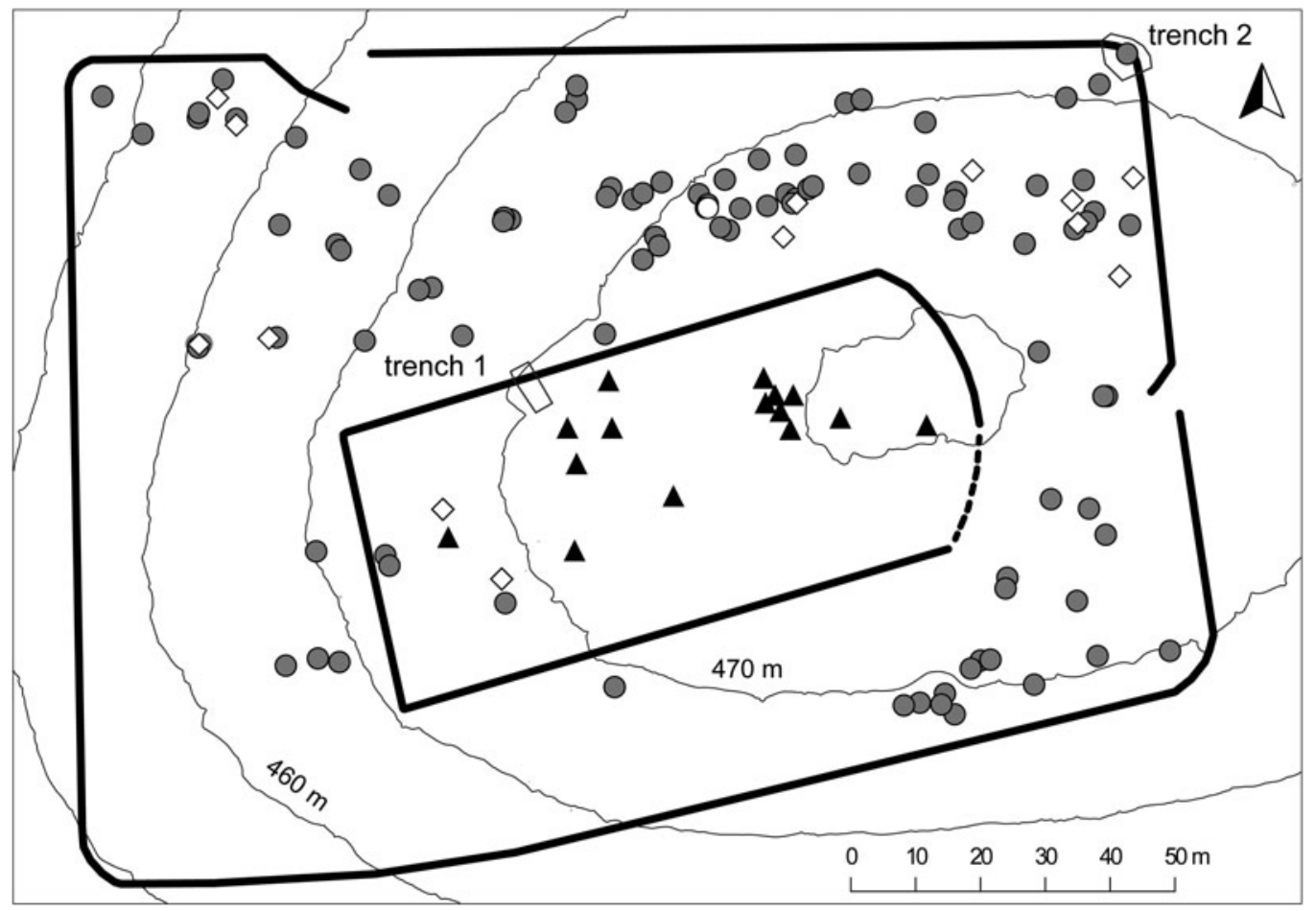

Fig. 2. Schematic plan of the Grociana piccola fortifications with the position of trenches 1 and 2 and the archaeological finds. Gray circles: caliga hobnails; black triangles: pottery; white diamonds: other metal finds; white circle: Roman coin.

have controlled a large sector of the Karst plateau not visible from the main San Rocco camp, which was built on the top of a marly-arenaceous hill, just $2 \mathrm{~km}$ away from the innermost present-day shore of Muggia Bay. ${ }^{8}$

LiDAR-derived images of Mt. Grociana piccola revealed a trapezoidal structure with blunt corners oriented east-west, containing a smaller sub-rectangular one with a different orientation (Fig. 2). The areas enclosed by the large and the small enclosures are ca. 2 ha and 0.4 ha respectively. On site, the remains of the defensive ramparts are recognizable as modest earth banks. ${ }^{9}$ Two internal clavicula entrances have been identified on the northern and eastern sides of the outer fortification and such entrances may also have been present on the western and southern sides, since it was common Roman practice to place an entrance on each side, topographical considerations permitting. ${ }^{10}$

\section{Surface surveys}

Ceramic finds

Ceramics were exclusively found inside the inner fortification. These are mostly amphora fragments and a few fragments of bases and body sherds belonging to smaller Roman

\footnotetext{
Bernardini et al. 2015.

Bernardini et al. 2015.

10 Bernardini 2019.
} 
vessels, including thin-walled pottery. Three Lamboglia 2 amphora rims were discovered and attributed to the period between the late 2nd c. BCE and the first decades of the 1st c. BCE. ${ }^{11}$

\section{Metal finds}

Ninety-four caliga hobnails were found, mainly between the inner and outer ramparts (Fig. 2). Among them, the largest group includes 74 hobnails with cross-shaped embossed signs and four dots on their underside with diameters ranging from 11 to $22 \mathrm{~mm}$ and weights ranging from less than $3 \mathrm{~g}$ to more than $8 \mathrm{~g}$ (Fig. 3: 7). Among the other hobnails, 11 do not bear any marks, 4 have numerous small dots circularly arranged, 2 specimens retain a series of spaced larger dots, and 1 has a cross on it.

The most abundant hobnails, corresponding to the Alesia type $\mathrm{D}^{12}$ are well attested in Late Republican military sites in the period between Caesar's campaigns in Gaul and the beginning of the Augustan period, ${ }^{13}$ but they were probably already in use at the end of the 2nd c. BCE. ${ }^{14}$ The specimen with a cross corresponds to the Alesia type $\mathrm{B}^{15}$ which is also documented in other Late Republican military contexts, ${ }^{16}$ while the hobnails with very small circularly arranged dots can be ascribed to the first centuries CE. ${ }^{17}$ The few hobnails without marks and the specimens with spaced circularly arranged dots were in use for a long time during the Roman period. ${ }^{18}$

The other metal finds mostly come from the northern area of the outer fortification. They include a pointed and socketed iron weapon, most probably a spear/bolt head or spear butt (Fig. 3: 1). This is of a long-lasting type that has already been reported from the hoard of Roman Republican weapons found at nearby Grad, near Šmihel, ${ }^{19}$ which is dated to the first half of the 2 nd c. BCE. ${ }^{20}$ An iron rod might be a simple arrow head, similar to those also found at Grad (Fig. 3: 3), ${ }^{21}$ while an additional one shows an unusual head (Fig. 3: 4). ${ }^{22}$ It is worth mentioning a folded iron band that might be a fragment of a shield binding (Fig. 3: 5), ${ }^{23}$ and a further two, possibly Roman, artifacts: an iron ring (Fig. 3: 6), about $3 \mathrm{~cm}$ in diameter, and an iron point (Fig. 3: 2). Finally, a Republican as dating back to the first half of the 2nd c. BCE was found (for the findspot see Fig. 2). ${ }^{24}$

\footnotetext{
11 Bernardini et al. 2013, 2015.

12 Brouquier-Reddé and Deyber 2001, 304, pl. 93: D.

13 Istenič 2019, 273-79.

14 Deyber and Luginbühl 2018, 158, 160-61, fig. 14.3.

15 Brouquier-Reddé and Deyber 2001, 303-4, pl. 93: B.

16 Poux 2008, 376-81.

17 Bernardini et al. 2018, with relevant literature.

18 Bernardini et al. 2018, with relevant literature.

19 Horvat 2002, 140, 184, pl. 13: 6-14.

20 Horvat 2002, 129-35, 142-43; Laharnar 2015, 11-14.

21 Horvat 2002, 135-37, pl. 16: 31-37.

22 For comparanda from Alesia: Sievers 2001, 237, pl. 83: 684.

23 Sievers 2001, 145-46, pl. 45: 50-92.

$24 \quad$ For the details, see Bernardini 2019.
} 

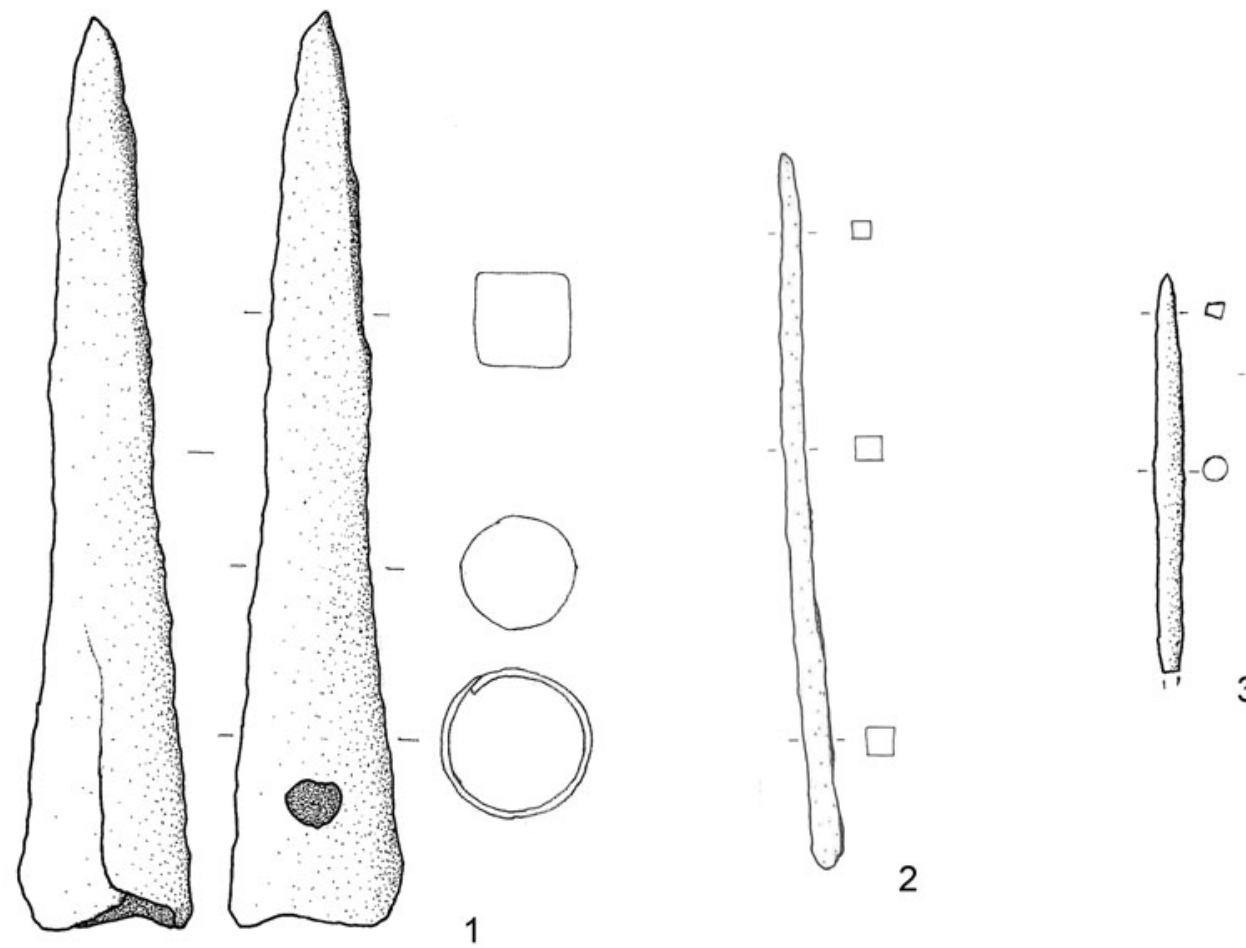

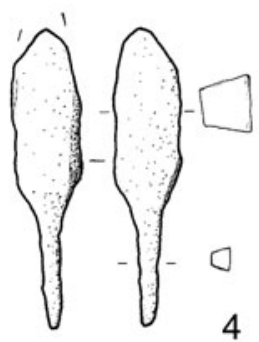

$2 \mathrm{~cm}$

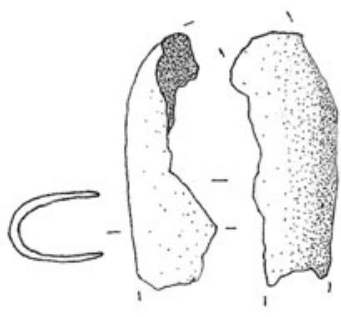

5

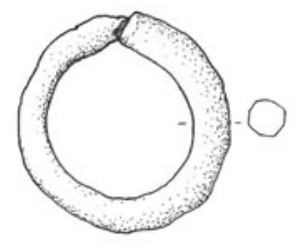

6
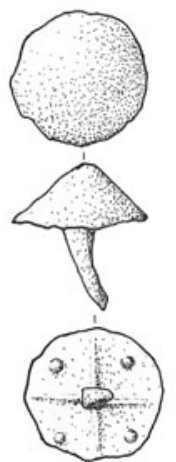

7

Fig. 3. Selection of metal finds from surveys. (Drawings by Andrea Fragiacomo.)

\section{Excavations}

\section{Trench 1}

The first trench investigated part of the inner rampart and its contiguous terrace (Fig. 2). Only dry-stone structures, mostly made of local limestone, and Roman pottery (total weight about $30 \mathrm{~kg}$ ) were uncovered. A dry-stone structure, interpreted as the rampart, was built directly onto the bedrock (stratigraphic unit [hereafter SU] 11; see Figs. 4-5 for SU locations). The remains of a thin ancient soil, no more than a few centimeters thick, were uncovered both north and south of the rampart (SU7 and SU9 respectively). The rampart was about $1.5 \mathrm{~m}$ wide and composed of two revetment walls formed of a single course of large blocks, $0.4-0.5 \mathrm{~m}$ across (SU4 and SU5), with a core of small stones (from 0.05 to $0.2 \mathrm{~m}$ across) and red sandy soil (SU3), most probably taken from elsewhere. It contained 


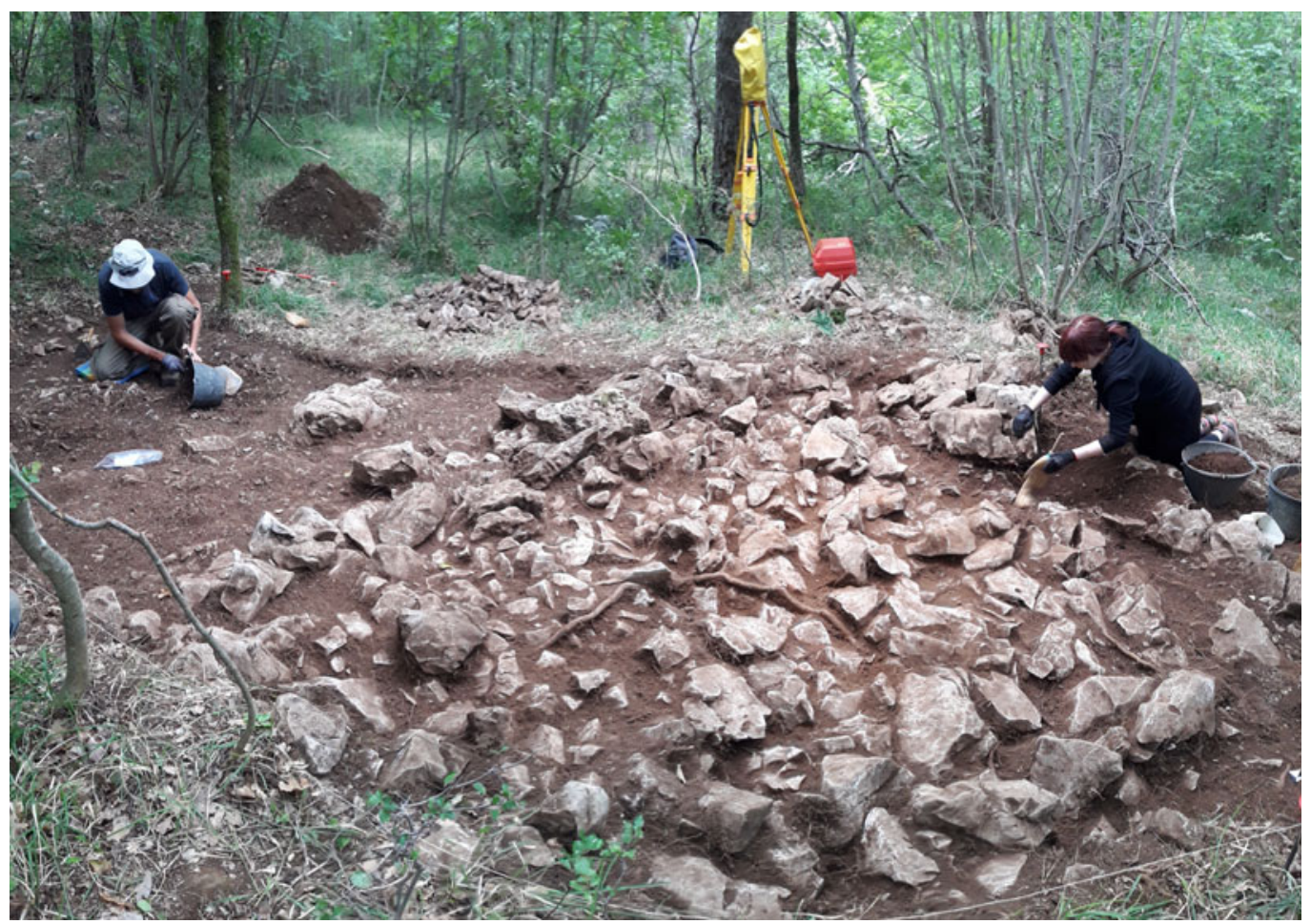

Fig. 4. Trench 1: inner rampart from northeast before the removal of tumbled blocks.

rare fragments of Roman pottery, some of them from the bottom of the layer (Fig. 7a: 3). An additional line of large stones (SU10), one of them made of sandstone, was discovered about $0.5 \mathrm{~m}$ away from the outer revetment wall, its central part partially slumping downwards. The space between SU5 and SU10, labeled as SU12, was filled with a brown soil containing rare charcoal. One fragment of charcoal was radiocarbon-dated, providing a calibrated age range of 199 BCE-86 CE at 95.4\% (Suppl. Fig. 1).

In the inner terrace, next to the inner revetment wall SU4, the occupation layer SU8 deepened toward the southern margin of the trench, where it filled natural depressions in the bedrock. It contained 1,398 amphorae remains, fragments of other ceramic vessels, including thin-walled pottery, and a caliga hobnail from the top of the layer (Fig. 6: 1-2, 4-5, 7-8, 10-17; Fig. 7a: 1-2, 4-9; Fig. 7b: 4). The layer can probably be interpreted as the result of a deliberate accumulation of material aimed at leveling the internal area of the fortification.

The collapse of the rampart SU2, which fell to the south of the inner revetment wall SU4, contained 418 amphora fragments and three caliga hobnails (Fig. 6: 3, 9; Fig. 7b: 1-3), suggesting that it was partially mixed up with the top of the underlying occupation layer SU8. SU6 corresponds to the collapse of the rampart to the north. The vegetation cover (SU1) contained rare Roman shards (Fig. 6: 6).

\section{Pottery and metal finds}

Amphora fragments prevail (almost 96\% of all pottery) in the layers SU8 and SU2. Most of these are body sherds, including large fragments, implying their primary accumulation. 


\section{Grociana piccola}

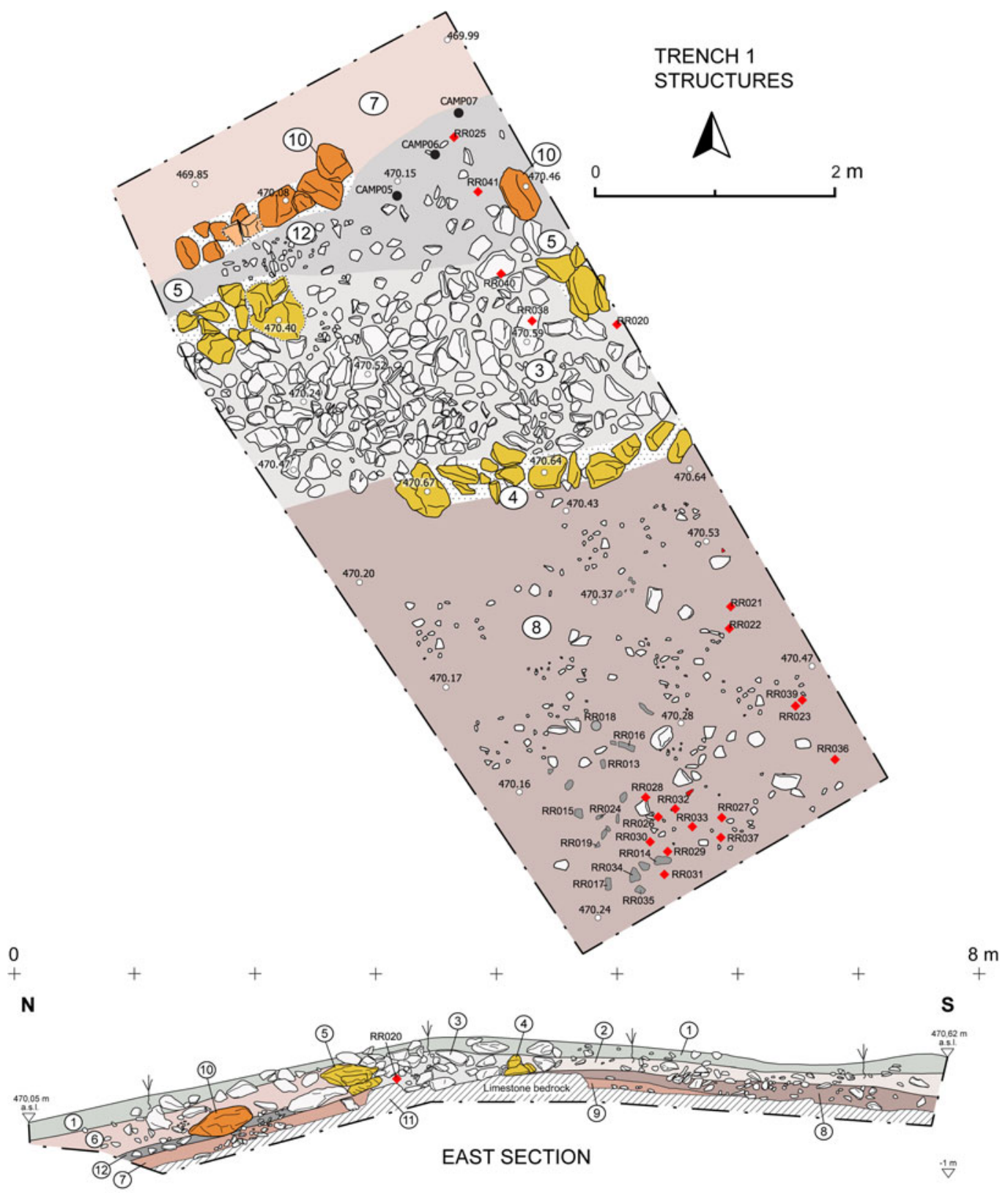

Fig. 5. Trench 1: plan of the trench after the removal of the collapse layers, and east cross section. Gray circle: caliga hobnail; diamonds: registered ceramic fragments; gray symbols in SU 8: other registered and unregistered ceramic fragments; black circles: organic and inorganic samples.

Eleven rims indicate the minimum number of amphorae. The fabric is typical for the Adriatic amphorae production (soft to hard; light colors - reddish yellow, pale yellow, pink; rare inclusions). ${ }^{25}$ Eight rims can be attributed to the Lamboglia 2 wine amphorae that were produced on the Italian side of the Adriatic (Fig. 6: 4-11). This type developed 
Federico Bernardini et al.

0

$5 \mathrm{~cm}$

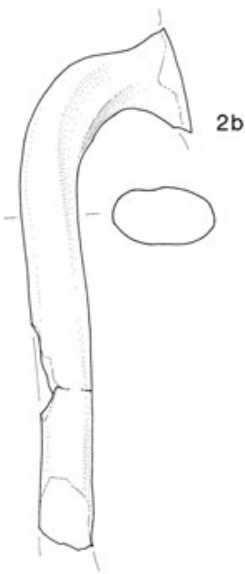

$\sum_{6}$
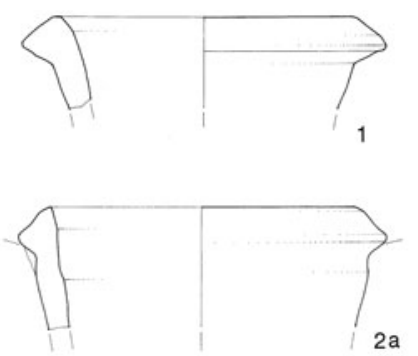

$2 a$
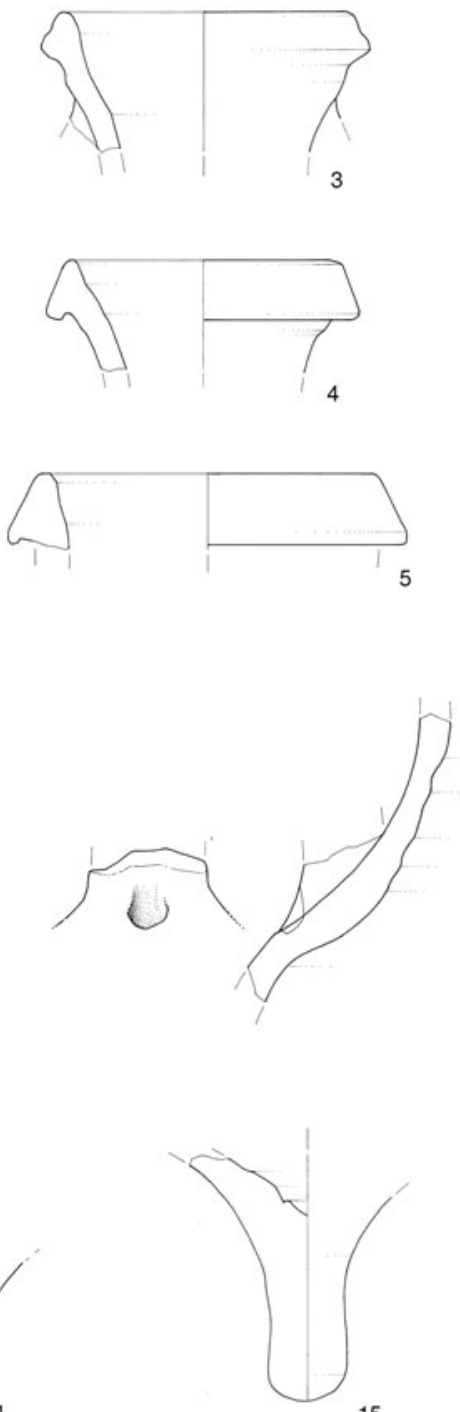

15
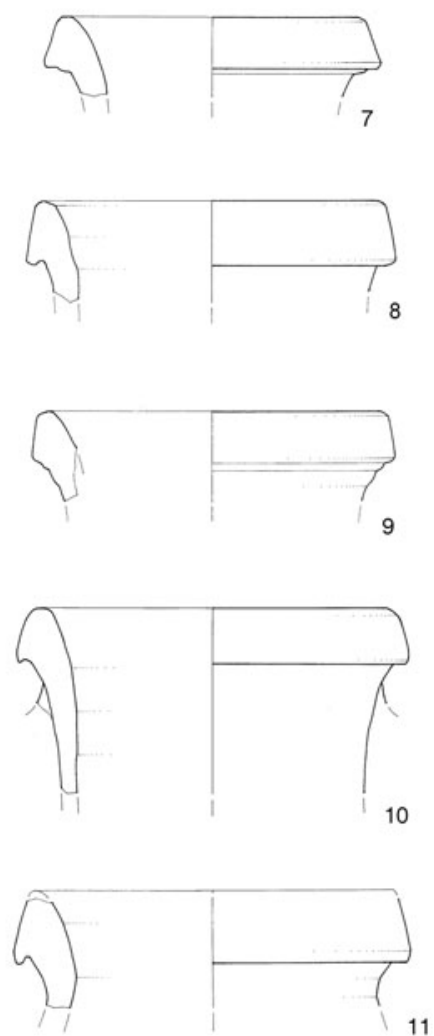

11
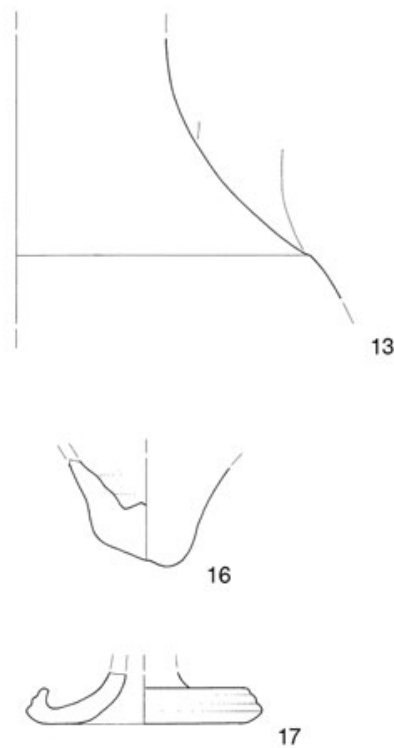

Fig. 6. Selected amphora remains from trench 1. 3, 9: SU 2; 6: SU 1; others SU 8. (Drawings by Tamara Korošec.) 


\section{Grociana piccola}

a
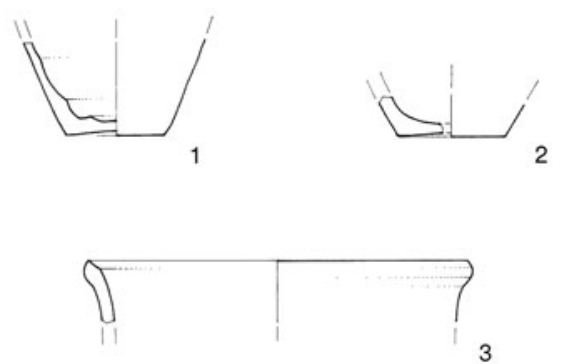

3
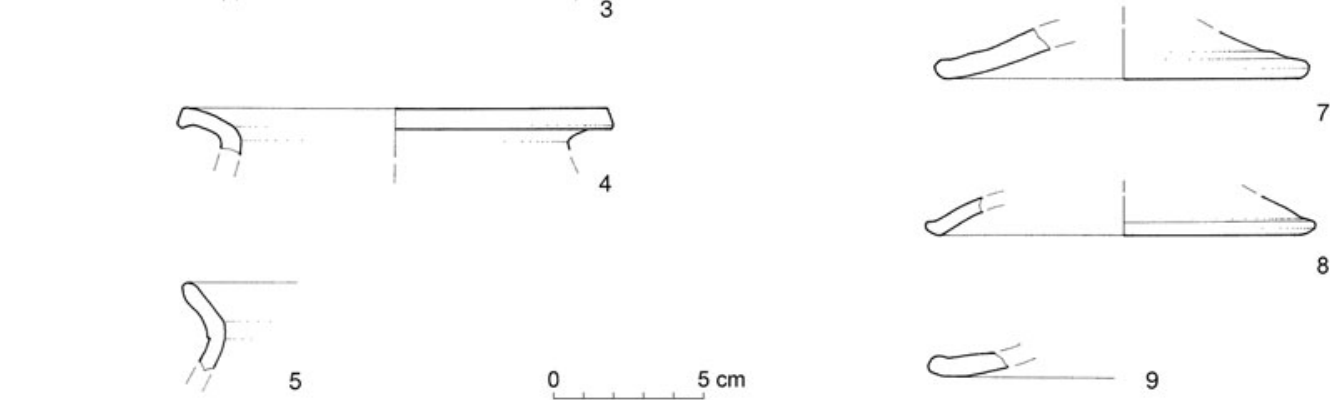

b
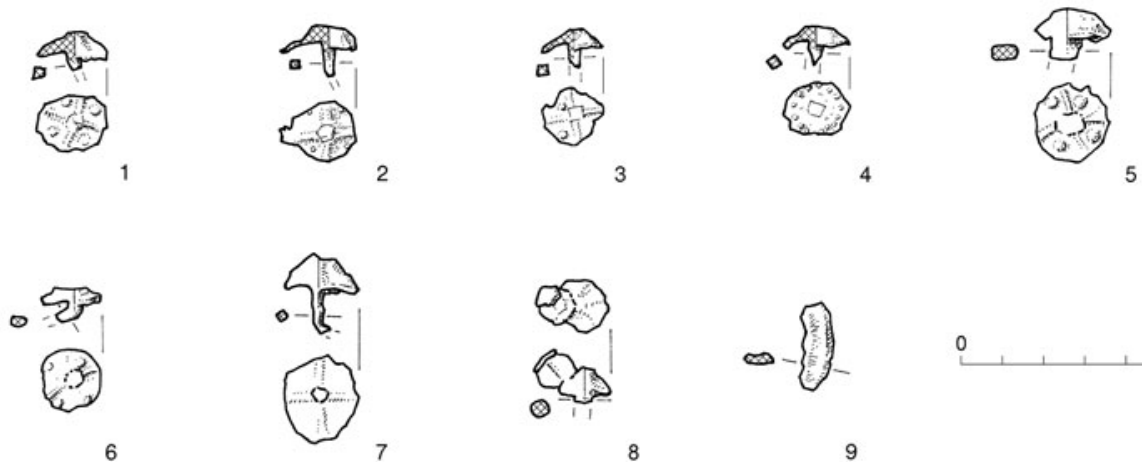
$5 \mathrm{~cm}$

Fig. 7. (a) Selected pottery from trench 1 (1-2, 4-9: SU 8; 3: SU 3); (b) metal finds from trenches 1 and 2 (1-3: SU 2; 4: SU 8; 5-9: SU 103). (Drawings by Tamara Korošec.)

in the middle or third quarter of the 2nd c. BCE from the Adriatic Greco-Italic amphorae and evolved into the Dressel 6 a amphorae in the third decade BCE. ${ }^{26}$

The rims of the Lamboglia 2 amphorae from Grociana piccola have a triangular cross section which is characteristic for the early phase of the type production. ${ }^{27}$ Three rims (Fig. 6: 1, 2a, 3) with the protruding triangular shape and a smaller dimension might be attributed to late Greco-Italic amphorae. Their form and fabric are similar to the late Greco-Italic amphorae from the nearby coastal site of Sermin. ${ }^{28}$ However, it is often difficult to distinguish the rims of the late Greco-Italic and early Lamboglia 2 types. $^{29}$

Carre and Pesavento Mattioli 2003, 269-71; Panella 2010, 17-21; Carre et al. 2014.

E.g., Bruno 1995, 27-38; Horvat 1997, 60-67; Forti and Paci 2008; Stoppioni 2011.

28 Horvat 1997, 60-67, fig. 20.

$29 \quad$ E.g. Horvat and Bavdek 2009, 84-85; Corti 2012, 115-18, 2017. 


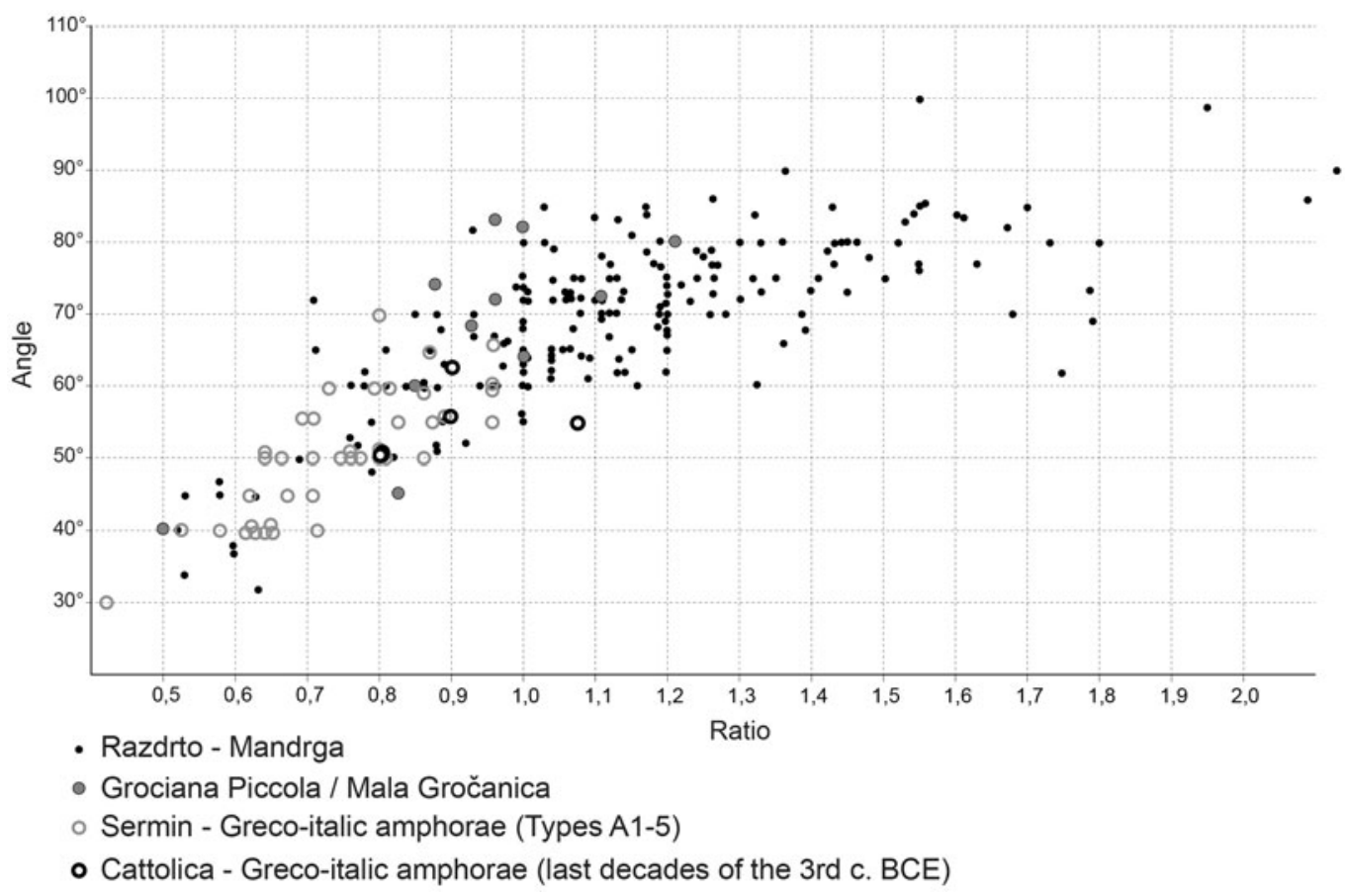

Fig. 8. Comparative morphometric analysis of amphora rims from trench 1(b). Angle: angle between the horizontal line and the exterior of the sloping rim edge; ratio: ratio between the height and the thickness of the rim.

A wheel-thrown amphora lid (Fig. 6: 17) could have been used for both Greco-Italic and Lamboglia $2 .^{30}$

In order to attempt to more closely date the Grociana piccola amphorae they have been compared with Lamboglia 2 amphorae from Razdrto-Mandrga, located on the Razdrto pass and dated to the end of the 2nd c. and beginning of the 1st c. BCE (Fig. 1); ${ }^{31}$ with the Greco-Italic amphorae from Sermin dated between the end of the 3rd c. and the third quarter of the 2nd c. BCE, ${ }^{32}$ and with a group of Greco-Italic amphorae from a kiln site in Cattolica (Emilia Romagna) dated to the end of the 3rd c. BCE. ${ }^{33}$ The starting point for the comparison was the general development of the amphora rims from the early triangular to the later banded forms. Three measures that determine the basic shape were taken on each rim: the angle between the horizontal line and the exterior of the sloping rim edge; the thickness (greatest width) of the rim; the height of the rim from the point of the greatest width to the top. The ratio between the height and the thickness was calculated in a second step. This ratio and the angle of the amphora rims are presented in Fig. 8 (for the morphometric measurements see Suppl. Fig. 2). ${ }^{34}$ The Grociana piccola amphora rims only partly match with those from Razdrto-Mandrga. Based on the presumption that a typo-chronological development is visible in the graph, it seems

30 Horvat 1997, 77-82, form PA 2.

31 Horvat and Bavdek 2009, 93-96.

$32 \quad$ Horvat 1997.

33 Stoppioni 2009.

34 For the method, see Horvat 1997, 62-67, fig. 20. 


\section{Grociana piccola}

that Grociana piccola amphorae are limited to a shorter period of time and are contemporary only with the earlier group of the Razdrto-Mandrga amphorae. The Grociana piccola rims attributed to late Greco-Italic shapes (Fig. 6: 1, 2a, 3) are more comparable with the Greco-Italic amphorae from Sermin and Cattolica. Results of morphometric analysis therefore indicate that the Grociana piccola amphorae should be dated in the 2nd c. BCE. Few rims are typologically comparable with Greco-Italic amphorae dated to the end of the 3rd c. and first half of the 2nd c. BCE and the remaining ones can be probably ascribed to the beginning of the Lamboglia 2 production, corresponding to the middle to second half of the 2nd c. BCE.

All of the other pottery from Grociana piccola has its origin in the Roman milieu and can be found in the region at the time of early Lamboglia 2 amphorae (Fig. 7a). Thin-walled beakers of Marabini 3 form (Fig. 7a: 1-2) emerged in the first half of the 2nd c. BCE in Tyrrhenian Italy and quickly spread across the entire peninsula and the wider western Mediterranean. The type was produced till the mid-1st c. BCE. ${ }^{35}$ The absence of cooking vessels (except one body fragment) indicates that the Grociana piccola layers were not connected with a typical settlement waste.

Three hobnails with a cross and four dots come from the collapse of the rampart SU2 (Fig. 7b: 1-3), while a hobnail with dots circularly arranged came from the top of SU8 (Fig. 7b: 4).

\section{Trench 2}

This trench investigated the northeastern corner of the outer rampart (Fig. 2). The limestone bedrock (SU104) was covered by a few centimeters of natural soil (SU103) that corresponded to the ancient walking surface (Fig. 9). A few hobnails were discovered on this surface (Fig. 7b: 5-6, 8). The rampart itself was a dry-stone structure, made of local limestone. The corner of the rampart was curved and made of an inner wall (SU105; less than $1 \mathrm{~m}$ wide and about $0.5 \mathrm{~m}$ high) and an outer line of large stones located at about $2 \mathrm{~m}$ from the inner structure at a slightly lower altitude (SU106). The space between these lines of stones was filled with smaller stones and earth (SU107).

Located to the rear of the rampart, a rectangular platform was uncovered (Figs. 9-10) that was made of two outer revetment walls (SU111 and SU112) composed of even large blocks with a core of smaller stones (SU108). The structure might be interpreted as a base of a tower or artillery platform.

The collapse of the rampart was represented by SU109 and SU110. These deposits were all covered by a shallow topsoil, SU101.

\section{Metal finds}

Three hobnails came from the walking surface SU103. One shows a cross with four dots (Alesia type D; Fig. 7b: 5), another one probably belongs to the same type but is very corroded (Fig. 7b: 6), while the last is without any sign (Fig. 7b: 8). An additional hobnail of the Alesia type D was found at the bottom of the rampart fill SU107 (Fig. 7b: 7; Suppl. Fig. 3). 
Federico Bernardini et al.

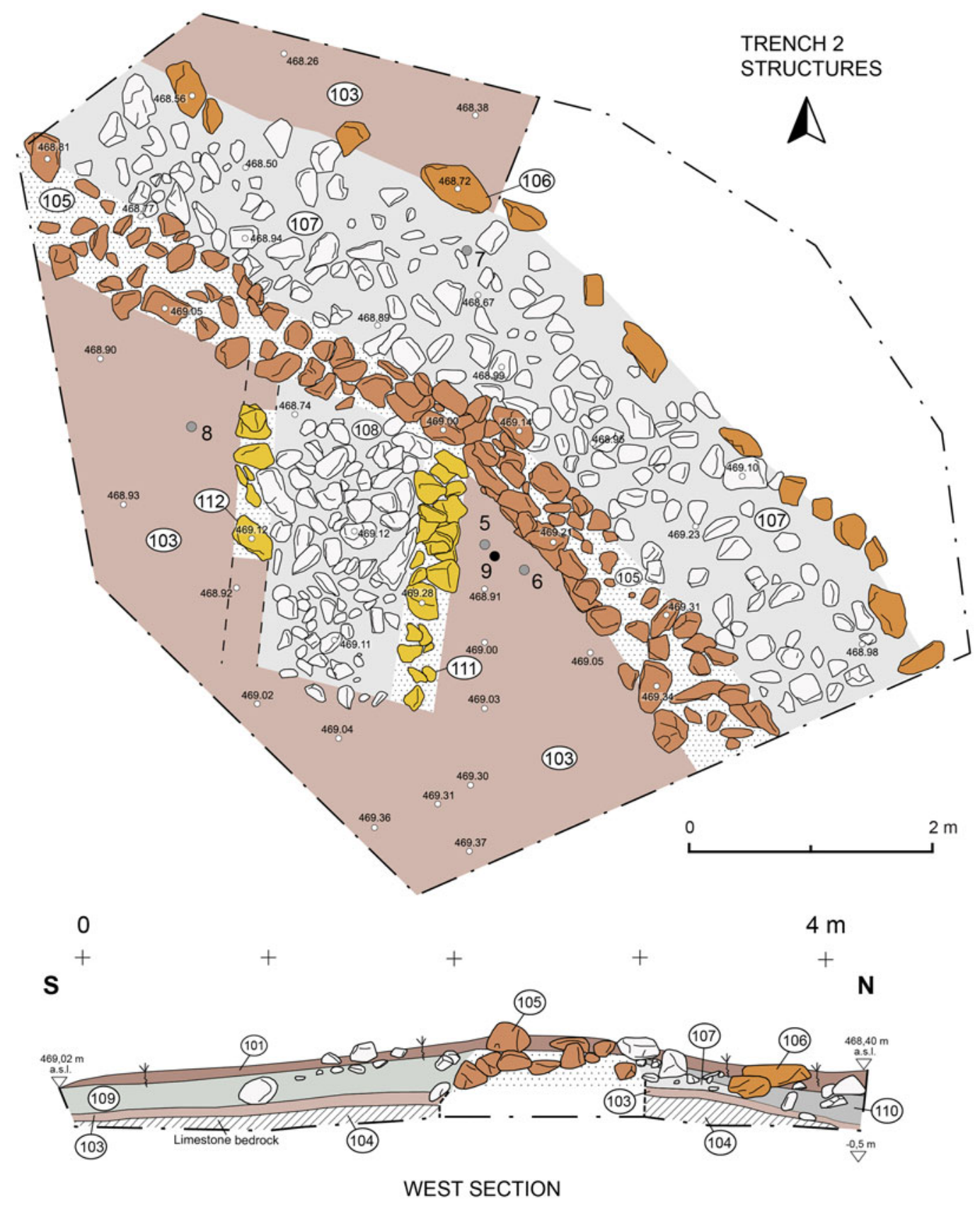

Fig. 9. Plan of trench 2 after the removal of the collapse layers, and west cross section. Gray circles: caliga hobnails; black circles: other metal finds. For the position of the section, see Fig. 10.

\section{Discussion}

Inner fortification

The inner rampart, as shown above, was only about $1.5 \mathrm{~m}$ wide. It was composed of two revetment walls made of large blocks, built directly onto the bedrock, and an unmortared core of smaller stones in a soil matrix. This structure, even in ancient times, must have been quite low (less than $1 \mathrm{~m}$ high); few blocks attributable to the structure could be found and 


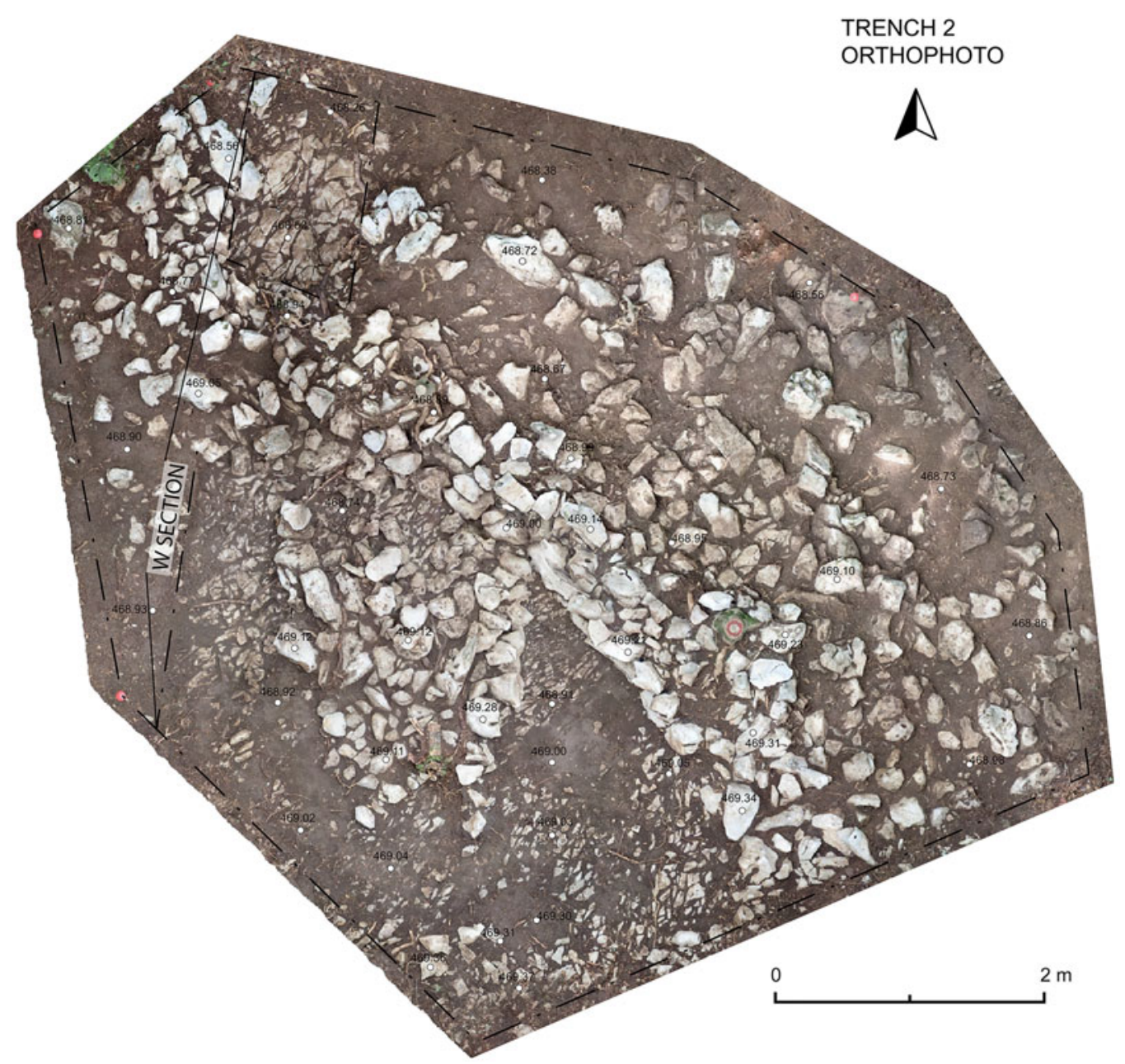

Fig. 10. Orthophoto of trench 2 after the removal of the collapse layers, with the position of the west cross section of Fig. 9.

the wall faces were made up of just a single course of blocks. Despite the rough technique, the pottery from the site confirms its Roman date. About $0.5 \mathrm{~m}$ from the northern revetment wall, parallel to the latter and at a slightly lower altitude, another row of large blocks was discovered (SU10), one of them made of sandstone. This was probably gathered from the closest Flysch outcrops, located about $0.5 \mathrm{~km}$ to the south. This additional row of stones perhaps supported an additional wooden defensive structure, located outside the main rampart. The low elevation of the rampart, and comparisons with Early Roman camps elsewhere, suggest that it was probably used as a protected walkway. ${ }^{36}$ In the camps of the Numantia area most of the attested ramparts are of the same building technique and modest height. ${ }^{37}$ Limiting our comparison to Renieblas, all the camps here were defended by low ramparts composed of two low revetment walls facing a core made of earth and

36 Dobson 2008; Morillo Cerdán 2014; Morillo Cerdán et al. 2011.

37 Dobson 2008; Morillo Cerdán 2014; Morillo Cerdán and Morales Hernández 2015. 
small stones, similar to what we have at Grociana piccola. While most of the ramparts at the Renieblas camps were much wider, those at Camps I and II were closer to the dimensions seen at Grociana piccola, ranging in width between 1.75 and $2.3 \mathrm{~m}$ at the former, and 1.85 and $2 \mathrm{~m}$ at the latter. ${ }^{38}$ On the other hand, the presence of an additional line of stones, close to and parallel with the outer face of the rampart of Grociana piccola, does not find a precise parallel among the fortifications in the area of Numantia or those at Pedrosillo. ${ }^{39}$

A so-called three wall rampart type, consisting of two revetment walls and an additional parallel row of large stones running down the center of the rampart, was identified by Schulten in some of the Numantia fortifications. According to Schulten, such a building technique would have been used to provide a slope up to the back of the rampart and/or to strengthen an unusually wide rampart. At Grociana piccola, however, the additional course of stones is located just outside the rampart at a slightly lower altitude. This makes the Grociana piccola rampart construction quite different from the "three wall" type, which in any case has recently been questioned by Dobson. ${ }^{40}$ Interestingly enough, stone alignments similar to that of Grociana piccola (SU10) have been discovered at Cáceres el Viejo (82-72 BCE), but they have been interpreted as a base of the rampart. ${ }^{41}$

Whatever the exact arrangement of the rampart, the ceramics from the occupation layers within the inner fortification date its occupation to the 2nd c. BCE. Its modest size (ca. 0.4 ha), its early chronology, and its strategic position and visual connection with the main San Rocco camp suggest that it may have been in use during the time of the Istrian war fought in 178-77 BCE and/or later military campaigns of the 2nd c. BCE aimed at controlling areas of the Karst plateau that were not visible from closer to the coast. It probably lost its strategic relevance when the area was relatively pacified.

\section{Outer fortification}

The northeastern corner of the outer rampart was curved and made of an inner wall alignment (less than $1 \mathrm{~m}$ wide and about $0.5 \mathrm{~m}$ high) and an outer irregular line of large stones located at about $2 \mathrm{~m}$ from the inner structure at a slightly lower altitude. A caliga hobnail of the Alesia type D was found at the bottom of the chaotic filling of stones placed between them. Three additional caliga hobnails (including the Alesia type D) have been found on the ancient walking level inside the rampart.

Just inside the corner of the fortification, a 2-m-wide rectangular platform was found. It consists of two parallel faces with an approximately north-south orientation and a filling made of smaller blocks arranged in no order. It shows the same height as the internal wall alignment and has been interpreted as a probable tower or artillery platform.

The inner wall alignment of the rampart and the rectangular platform could have been covered by earth/turf and/or wooden planks to be used as a platform and a walkway, respectively. They were perhaps defended by non-permanent wooden structures, such as

Dobson 2008; Morillo Cerdán et al. 2011; Morillo Cerdán 2014; Morillo Cerdán and Morales Hernández 2015.

40 Dobson 2008, 190, 245-56, 401-2, fig. 279b and 279d.

41 Abásolo Álvarez et al. 2008. 


\section{Grociana piccola}

branches and/or the so-called chevaux-de-Frise stakes, housed in the area between the inner wall alignment and the external line of large stones.

Similar towers or artillery platforms located to the rear of the ramparts are already known from the camps of Renieblas and the Numantia fortification system, though these are not found at the corners of those sites with sub-rectangular plans, such as Camps IV and V of Renieblas. ${ }^{42}$ This being said, only one corner of Camp IV was found during excavation and no towers at all were identified at this site. ${ }^{43}$ In the later Cáceres el Viejo camp, which shows a regular rectangular layout, towers are missing and, as far as we know, angular towers have not been found at Caesarean camps either. We can conclude that the structure of Grociana piccola is one of the first examples of the angular platform/tower that would become a distinctive feature of most Imperial-era camps. ${ }^{44}$

Its clavicula entrances, known from the second quarter of the 1 st c. BCE, ${ }^{45}$ its regular plan, which in Spain seems not to appear before the beginning of the 1 st c. BCE, ${ }^{46}$ and the large number of type D caliga hobnails suggest that the outer structure at Grociana piccola has to be dated to the 1st c. BCE. Republican asses minted in the 2nd c. BCE, such as the one from the outer fortification, were still in use during the 1st c. BCE and have been discovered in other nearby military sites of approximately the same period. ${ }^{47}$ The absence of internal buildings and ceramics, the abundance of hobnails mostly belonging to the same type, and the rough construction technique of the rampart indicate that the camp was only used temporarily.

\section{Conclusions}

Grociana piccola provides a rare example of Republican military fortifications in the Caput Adriae and in Italy. The early chronology of the inner fortification, dated to the 2nd c. BCE by associated pottery, and its small size suggest that it was part of the fortification system controlled by the larger San Rocco camp, strategically located about $4 \mathrm{~km}$ to the south, very close to the ancient seashore of the Muggia Bay in the Trieste gulf. ${ }^{48}$ Several conflicts in this region are reported in the 2nd c. BCE by literary sources before and after the foundation of Aquileia in 181 BCE. ${ }^{49}$ The earliest, known as the First Istrian War, between Rome and the inhabitants of Istria, occurred in $221 \mathrm{BCE}^{50}$ Later, in $183 \mathrm{BCE}$, the Romans forced a Celtic tribe, who had settled a few years earlier not far from the future colony of Aquileia, to move back to their territory beyond the Alps. Other clashes between the Romans and the Histri occurred during the foundation of Aquileia, an episode labeled the Second Istrian War by some scholars. ${ }^{51}$ However, it was only during 178-77 BCE that

\footnotetext{
Dobson 2008; Morillo Cerdán and Morales Hernández 2015.

Dobson 2008.

Fischer 2012, 256-59.

See references in Laharnar 2013.

Morillo Cerdán et al. 2017.

Laharnar 2016.

Bernardini et al. 2015.

Bandelli 2004, 101-5, with relevant literature; Šašel Kos 2005, 321-29, with relevant literature.

Bandelli 2004, 101.

Bandelli 2004, 102, with relevant literature.
} 
Istria was conquered, during the conflict variously labeled the Second or Third Istrian War. $^{52}$

In $176 \mathrm{BCE}$, a garrison of socii nominis Latini was stationed in the Istrian territory to control the indigenous population; in $171 \mathrm{BCE}$, the consul G. Cassius Longinus mistreated the Histri, Carni, and Iapodes. ${ }^{53}$ In 129 BCE, further military expeditions were undertaken against the Taurisci, Histri, Iapodes, and perhaps Carni and Liburni, ${ }^{54}$ in 119 BCE against the Segestani, ${ }^{55}$ and then in $115 \mathrm{BCE}$ against the Carni. ${ }^{56}$ The establishment of the Grociana piccola inner fortification and the large San Rocco camp could have been related to any one of these military episodes but the sites could have also played a role in other conflicts not mentioned in the historical sources. However, among the historically documented campaigns, it is worth stressing that the war fought in $178 \mathrm{BCE}$ (the Second or Third Istrian War) is the only one that probably took place in the immediate vicinity of Trieste.

Regardless of the precise moment when the Grociana piccola inner fortification was built, it provides one of the earliest and smallest examples of a Roman military fort, with the rampart being constructed using the same building technique as much larger 2nd-c. BCE military camps. In contrast, the archaeological data suggest that the outer fortification at Grociana piccola was in use for a short time during the first half of or mid-1st c. BCE. During this period, the literary sources report several Roman military campaigns against the populations of the northern Balkans, mainly the Iapodes. The Romans probably defeated them, together with the Liburni and Taurisci, between 78 and $76 \mathrm{BCE}^{57}$ and carried out at least two further, but unsuccessful, campaigns in the period of approximately 55-35 BCE. ${ }^{58}$ In 52 BCE, the Iapodes plundered Trieste and threatened Aquileia. ${ }^{59}$ They were only definitively defeated, together with the Pannonii and Delmatae, by Octavian in 35-34 BCE. ${ }^{60}$ The outer camp of Grociana piccola may have been built in the context of military operations aimed at countering the threat posed by Iapodes, possibly in connection with these intense military activities reported during the mid-1st c. BCE.

Supplementary Materials: Results of radiocarbon analysis and three associated figures can be found in the Supplementary Materials. These can be viewed at https://doi.org/10.1017/S1047759421000453.

\section{References}

Abásolo Álvarez, J. A., M. L. González Fernández, and B. Mora Serrano. 2008. “Recientes investigaciones en el Campamento de Cáceres el Viejo, Arqueología urbana en Cáceres." In Investigaciones e intervenciones recientes en la ciudad de Cáceres y su entorno, ed. P. J. Sanabria, 115-43. Cáceres: Editora regional de Extremadura.

Bandelli, G. 2004. "Momenti e forme nella politica illirica della repubblica romana (229-49 a.C.)." In Dall'Adriatico al Danubio. L'Illirico nell'età Greca e Romana, ed. G. Urso, 95-139. Pisa: Edizioni ETS.

\footnotetext{
52 Bandelli 2004, 102, with relevant literature.

53 Bandelli 2004, 103, with relevant literature.

54 Bandelli 2004, 104, with relevant literature; Chiabà 2017, 173.

55 Bandelli 2004, 104, with relevant literature.

56 Bandelli 2004, 105, with relevant literature.

$57 \quad$ Dzino 2010, 74.

58 Šašel Kos 2000, 282.

59 Šašel Kos 2000, 292; Dzino 2010, 85.

60 Šašel Kos 2018.
} 


\section{Grociana piccola}

Bernardini, F. 2019. “Fortificazioni militari repubblicane nell'area di Trieste (Italia nord-orientale): materiali archeologici da Grociana piccola e San Rocco rinvenuti nel corso della prima campagna di ricognizioni." In Accampamenti, guarnigioni e assedi durante la Seconda Guerra Punica e la conquista romana (secoli III-I a.C.): prospettive archeologiche, ed. B. Vallori Márquez, C. Rueda Galán, and J. P. Bellón Ruiz, 139-53. Rome: Quasar.

Bernardini, F., A. Sgambati, M. Montagnari Kokelj, C. Zaccaria, R. Micheli, A. Fragiacomo, C. Tiussi, D. Dreossi, C. Tuniz, and A. De Min. 2013. "Airborne LiDAR application to karstic areas: The example of Trieste province (north-eastern Italy) from prehistoric sites to Roman forts." JAS 40: 2152-60.

Bernardini, F., G. Vinci, E. Forte, S. Furlani, M. Pipan, S. Biolchi, A. De Min, A. Fragiacomo, R. Micheli, P. Ventura, and C. Tuniz. 2018. "Discovery of ancient Roman 'highway' reveals geomorphic changes in karst environments during historic times." PLoS ONE 13(3). https://doi.org/ 10.1371/journal.pone.0194939.

Bernardini, F., G. Vinci, J. Horvat, A. De Min, E. Forte, S. Furlani, D. Lenaz, M. Pipan, W. Zhao, A. Sgambati, M. Potleca, R. Micheli, A. Fragiacomo, and C. Tuniz. 2015. “Early Roman military fortifications and the origin of Trieste, Italy." ProcNatAcadSciUSA 112: 1520-29.

Brouquier-Reddé, V., and A. Deyber. 2001. "Fourniment, harnachement, quincaillerie, objets divers." In Alesia, fouilles et recherches franco-allemandes sur les travaux militaires romains autour $d u$ Mont-Auxois (1991-1997). Vol. 2, Le materiel, ed. M. Reddé and S. von Schnurbein, 293-362. Mémoires de l'Académie des inscriptions et belles-lettres 22. Paris: Académie des inscriptions et belles-lettres.

Bruno, B. 1995. Aspetti di storia economica della Cisalpina romana. Studi e ricerche sulla Gallia Cisalpina 7. Rome: Quasar.

Carre, M.-B., P. Monsieur, and S. Pesavento Mattioli. 2014. “Transport amphorae Lamboglia 2 and Dressel 6A: Italy and/or Dalmatia? Some clarifications." JRA 27: 417-28.

Carre, M.-B., and S. Pesavento Mattioli. 2003. "Anfore e commerci nell'Adriatico." In L'archeologia dell'Adriatico dalla preistoria al medioevo, ed. F. Lenzi, 268-85. Florence: All'Insegna del Giglio.

Chiabà, M. 2017. “Epigrafia e politica dall'urbe alla provincia. Il caso dell'icrizione trionfale di Gaio Sempronio Tuditano (cos. 129 a.C.)." In Epigrafia e politica. Il contributo della documentazione epigrafica allo studio delle dinamiche politiche nel mondo romano, ed. S. Segenni and M. Bellomo, 17195. Milan: Ledizioni.

Corti, C. 2012. "Anfore d'età repubblicana." In Ventidue secoli a Parma, ed. M. Marini Calvani, 115-28. BAR-IS 2406. Oxford: Archeopress.

Corti, C. 2017. "Le anfore della fornace di Torre delle Oche e la commercializzazione del vino in età repubblicana a Mutina." In Mutina splendidissima, 285-87. Rome: De Luca editori d'arte.

Deyber, A., and T. Luginbühl. 2018. "Cimbri and Teutones against Rome: First research results concerning the Battle of Arausio (105 BC)." In Conflict Archaeology: Materialities of Collective Violence from Prehistory to Late Antiquity, ed. M. Fernández-Götz and N. Roymans, 155-66. New York: Routledge.

Dobson, M. 2008. The Army of the Roman Republic: The Second Century BC, Polybius and the Camps at Numantia, Spain. Oxford: Oxbow Books.

Dzino, D. 2010. Illyricum in Roman Politics, 229 BC-AD 68. Cambridge: Cambridge University Press.

Fischer, T. 2012. Die Armee der Caesaren. Regensburg: Verlag Friedrich Pustet.

Forti, S., and G. Paci. 2008. "Le anfore Lamboglia 2 dal porto romano di Ancona." RCRFActa 40: $315-23$.

Gamberini, A. 2011. "Problemi di identificazione di aree produttive di anfore in ambito Adriatico: I dati archeologici e archeometrici di Suasa." Ocnus 19: 245-54.

Horvat, J. 1997. Sermin: A Prehistoric and Early Roman Settlement in Northwestern Istria. Opera Instituti Archaeologici Sloveniae. Ljubljana: Inštitut za arheologijo, Založba ZRC.

Horvat, J. 2002. “The Hoard of Roman Republican Weapons from Grad near Šmihel.” Arheološki vestnik 53: 117-92.

Horvat, J., and A. Bavdek. 2009. Okra. Vrata med Sredozemljem in srednjo Evropo / Ocra: The Gateway Between the Mediterranean and Central Europe. Opera Instituti Archaeologici Sloveniae 17. Ljubljana: Inštitut za arheologijo, Založba ZRC.

Istenič, J. 2019. "Caligati in the eastern hinterland of Aquileia up to the Early Augustan period." In Chronologie und vergleichende Chronologien zum Ausgang der Römischen Republik und zur Frühen 
Kaiserzeit, ed. H. Dolenz and K. Strobel, 271-94. Kärntner Museumsschriften 87. Klagenfurt: Landesmuseums für Kärnten.

Jiménez, A., J. Bermejo, R. Liceras, F. Moreno, and K. Tardio. 2017. “Archaeological perspectives on the siege of Numantia: The new fieldwork project at the Roman camps at Renieblas (Spain, 2nd-1st c. BCE)." In Conflict Archaeology: Materialities of Collective Violence in Late Prehistoric and Early Historic Europe, ed. M. Fernández-Götz and N. Roymans, 115-26. New York: Routledge.

Jiménez, A., J. Bermejo, P. Valdés, F. Moreno, and K. Tardio. 2020. “Renewed work at the Roman camps at Renieblas near Numantia (2nd-1st c. B.C.)." JRA 33: 4-35.

Laharnar, B. 2013. “The Roman stronghold at Nadleški hrib, Notranjska region." Arheološki vestnik 64: 123-47.

Laharnar, B. 2015. "The Roman army in the Notranjska region." In Evidence of the Roman Army in Slovenia, ed. J. Istenič, B. Laharnar, and J. Horvat, 9-41. Katalogi in monografije 41. Ljubljana: Narodni muzej Slovenije.

Laharnar, B. 2016. "Small finds from the Roman fort at Nadleški hrib, the Notranjska region (SW Slovenia)." In The Roman Army between the Alps and the Adriatic Europe, ed. J. Horvat, 85-97. Opera Instituti Archaeologici Sloveniae 31. Ljubljana: Inštitut za arheologijo, Založba ZRC.

Menchelli, S., M. Pasquinucci, C. Capelli, R. Cabella, and M. Piazza, 2008. "Anfore adriatiche nel Piceno meridionale." RCRFActa 40: 379-92.

Morillo Cerdán, Á. 2014. “Campamentos y fortificaciones tardorrepublicanas en Hispania: 'Calibrando' a Sertorio." In Las guerras civiles en Hispania, ed. F. Sala and J. Moratalla, 35-50. Alicante: Publicacions Universitat Alacant.

Morillo Cerdán, Á., and F. Morales Hernández. 2015. “Campamentos romanos de la guerra de Numancia: La circumvalación escipiónica." In Los Escipiones. Roma conquista Hispania, ed. M. Bendala, 275-98. Alcalá de Henares: Comunidad de Madrid.

Morillo Cerdán, Á., F. Morales Hernández, and R. Durán Cabello. 2017. “Schulten y los campamentos romanos republicanos en Hispania: Una mirada desde el siglo XXI." In Schulten y el descubrimiento de Numantia, 177-200. Madrid: Comunidad de Madrid.

Morillo Cerdán Á., G. Rodríguez Martín, E. Martín Hernández, and R. Durán Cabello. 2011. “The Roman Republican battlefield at Pedrosillo (Casas de Reina, Badajoz, Spain): New research (2007)." Conimbriga 50: 59-78.

Panella, C. 2010. "Roma, il suburbio e l'Italia in età medio- e tardo-repubblicana: Cultura materiale, territori, economie." Facta 4: 11-123.

Poux, M. 2008. "L'empreinte du militaire tardo-républicain dans les faciès mobiliers de La Tène finale." In Sur les traces de Cesar. Militaria tardo-republicains en contexte gaulois, 299-432. Bibracte: Centre archéologique européen.

Šašel Kos, M. 2000. "Caesar, Illyricum, and the hinterland of Aquileia." In L'ultimo Cesare, ed. G. Urso, 277-304. Monografie 20. Rome: Centro ricerche e documentazione sull'antichità classica.

Šašel Kos, M. 2005. Appian and Illyricum. Situla 43. Ljubljana: Narodni muzej Slovenije.

Šašel Kos, M. 2018. “Octavian's Illyrian war: Ambition and strategy." In The Century of the Brave: Roman Conquest and Indigenous Resistance in Illyricum during the Time of Augustus and His Heirs. Proceedings of the International Conference (Zagreb, 22-26. 9. 2014), ed. M. Milićević Bradač and D. Demicheli, 41-57. Zagreb: FF Press.

Sievers, S. 2001. "Les armes d'Alésia." In Alesia, fouilles et recherches franco-allemandes sur les travaux militaires romains autour du Mont-Auxois (1991-1997). Vol. 2, Le materiel, ed. M. Reddé and S. von Schnurbein, 121-291. Mémoires de l'Académie des inscriptions et belles-lettres 22. Paris: Académie des inscriptions et belles-lettres.

Stoppioni, M. L. 2009. “Cattolica (Rimini): Discarica di anfore greco-italiche.” In Olio e pesce in epoca romana, ed. S. Pesavento Mattioli and M.-B. Carre, 301-7. Atenor quaderni 15. Rome: Quasar.

Stoppioni, M. L. 2011. "Anfore a Rimini in età romano-repubblicana: Dalle greco italiche alla Lamboglia 2." Ocnus 19: 209-22.

Vinci, G., F. Bernardini, and S. Furlani. 2019. “Geo-archaeology of the Grozzana area (N-E Italy).” JMaps 15(2): 697-707. 